\title{
DAMAGE ANALYSIS OF TENSIONING CABLE ANCHORAGE ZONE OF A BRIDGE SUPERSTRUCTURE, USING CDP ABAQUS MATERIAL MODEL
}

\author{
J. CHRÓŚCIELEWSKI ${ }^{1}$, M. MIŚKIEWICZ ${ }^{2}$, L. PYRZOWSKI ${ }^{3}$, \\ B. SOBCZYK ${ }^{4}$
}

\begin{abstract}
Numerical analysis of the tensioning cables anchorage zone of a bridge superstructure is presented in this paper. It aims to identify why severe concrete cracking occurs during the tensioning process in the vicinity of anchor heads. In order to simulate the tensioning, among others, a so-called local numerical model of a section of the bridge superstructure was created in the Abaqus Finite Element Method (FEM) environment. The model contains all the important elements of the analyzed section of the concrete bridge superstructure, namely concrete, reinforcement and the anchoring system. FEM analyses are performed with the inclusion of both material and geometric nonlinearities. Concrete Damage Plasticity (CDP) constitutive relation from Abaqus is used to describe nonlinear concrete behaviour, which enables analysis of concrete damage and crack propagation. These numerical FEM results are then compared with actual crack patterns, which have been spotted and inventoried at the bridge construction site.
\end{abstract}

Keywords: Bridge failure, Concrete damage plasticity (CDP), Concrete cracking, FEM analysis, ABAQUS

\footnotetext{
${ }^{1}$ Prof., DSc., PhD., Eng., Gdańsk University of Technology, Faculty of Faculty of Civil and Environmental Engineering, ul. G. Narutowicza 11/12, 80-233 Gdańsk, Poland, e-mail: jchrost@pg.gda.pl

${ }^{2}$ PhD., Eng., Gdańsk University of Technology, Faculty of Faculty of Civil and Environmental Engineering, ul. G. Narutowicza 11/12,

80-233 Gdańsk, Poland, e-mail: mmisk@pg.gda.pl

${ }^{3}$ PhD., Eng., Gdańsk University of Technology, Faculty of Faculty of Civil and Environmental Engineering, ul. G. Narutowicza 11/12, 80-233 Gdańsk, Poland, e-mail: lpyrzow@pg.gda.pl

${ }^{4}$ PhD., Eng., Gdańsk University of Technology, Faculty of Faculty of Civil and Environmental Engineering, ul. G. Narutowicza 11/12, 80-233 Gdańsk, Poland, e-mail: barsobcz@pg.gda.pl
} 


\section{INTRODUCTION - THE AIM OF THE PAPER}

The bridge analyzed is a multi-span, continuous, box cross-section beam with external tensioning cables. Additionally, longitudinal centric prestressing of the cross-section was designed for the stages of superstructure erection. The cross-section of the bridge is shown in Fig. 1, where the ducts of centric prestressing cables are marked with green ellipses. The distance between adjacent duct axes of centric tensioning is equal to $250 \mathrm{~mm}$.

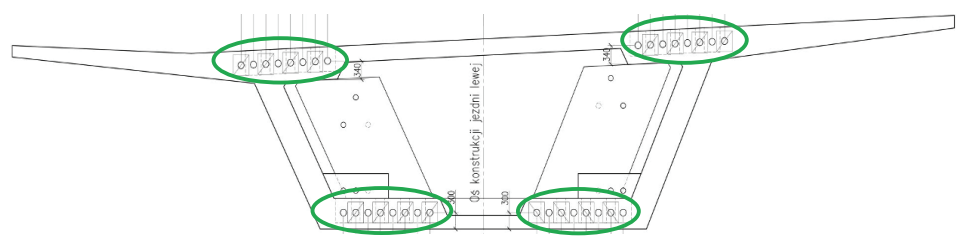

Fig. 1. Cross-section of the analyzed bridge with the ducts of centric prestressing marked with green ellipses.

Severe damage of the top tendon anchor zones in several spans was detected during the operation of centric prestressing. Basically, lateral concrete cracks and fractures appeared in the zone of anchor heads, despite the fact that reinforcement grids were applied. Concrete damage and a sketch of the anchor zone reinforcement grids are shown in Fig. 2. It is important to mention that an empty duct appeared between the two adjacent active ones during the centric prestressing as a result of the devised sequence of subsequent span erection (see Fig. 2 as well).

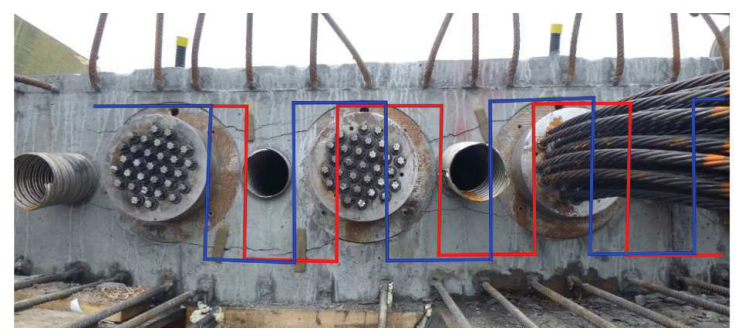

Fig. 2. Damages and sketches of anchor zone reinforcement grids.

In this paper, we attempt to identify and describe the failure mechanisms of the longitudinal tensioning cable anchoring zones of a selected bridge span, using the ABAQUS system finite 
element method (FEM) environment. Numerical calculations are therefore performed to simulate undesirable local cracking of the anchoring zones which appeared during prestressing. This is done to determine, from a mechanical point of view, the reasons why the cracking occurred, with regard to the design and construction of the reinforcements of the anchoring zones.

\section{NUMERICAL MODELS}

Our intention regarding numerical modelling was to pinpoint the cause of concrete failure in the shortest possible time.

At first we checked if the strength properties of the concrete at hand were sufficient to withstand the prestressing force. Therefore, a simple quasi-axisymmetric model of a concrete specimen with anchorages, additional reinforcement of the anchor zone, and only one loaded tendon duct was considered. Visualisation of the first model's geometry is shown in Fig. 3.

a)

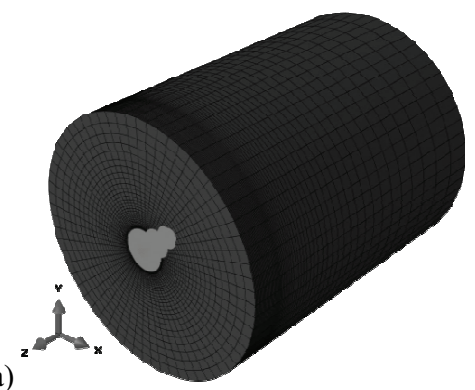

b)

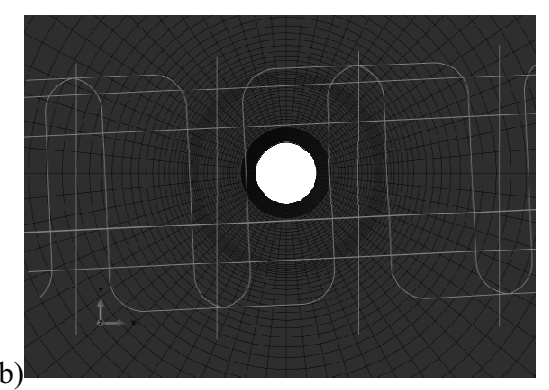

Fig. 3. Visualisation of the quasi-axisymmetric model: a) concrete and anchor head highlighted in light grey;

b) reinforcement of the anchor zone coloured in light grey.

Nevertheless, static calculations along with material and geometrical nonlinearities did not reveal any symptoms of concrete failure when the total stressing load was applied to the duct. Hence, a different model had to be created in order to find the cause of the damage.

As a consequence of the local focus of the failure phenomenon, we limit the geometry of the second model to only a specific part of the upper deck slab of the bridge box section, however, including all the elements that form the concrete structure (concrete, slab reinforcement, anchorage reinforcement grid, and anchor heads). The ducts are arranged in a single row with the same spacing and the active ones are tensioned with the same force (refer to Fig. 2). Thus, it is possible to identify 
planes of vertical cyclic symmetry which pass through the geometrical centre of the anchor heads. In effect, only one empty and two adjacent active ducts are taken into consideration in the model. Moreover, it is also possible to apply symmetry regarding the length of the ducts. Therefore, the external geometry of the second model is shown in Fig. 4a. Visualisation of the anchor heads is depicted in Fig. $4 \mathrm{~b}$ in light grey Reinforcement of the concrete slab and the anchorage grids are presented in Fig. 5a, b.

The boundary conditions applied to the model correspond to the symmetry planes which were described in the previous paragraph. The axial stressing of the tendons, taking into account the specificity of contact of the stressing unit, is realized via kinematic coupling between the front face of each considered anchor head and its corresponding point, the centre point of the tendon duct on the front face of the model (as shown schematically in Fig. 5c). Concentrated forces are applied to the points to induce stressing of the active ducts. Additionally, vertical displacements of the aforementioned points are restrained to protect against any rigid vertical translation of the model.

a)

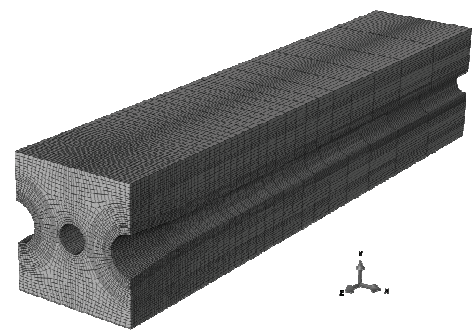

b)

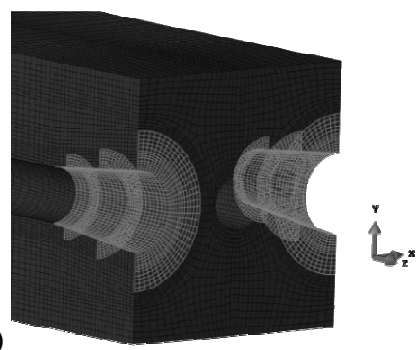

Fig. 4. a) External geometry of the model. b) Steel anchor heads (light grey) in the numerical model.

a)

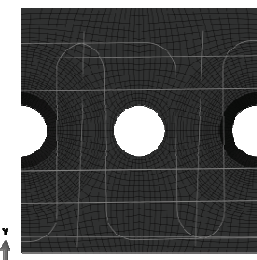

b)

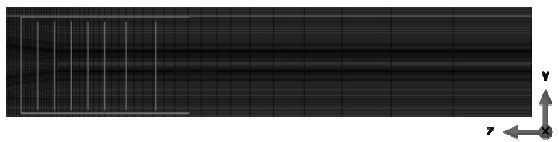

c)

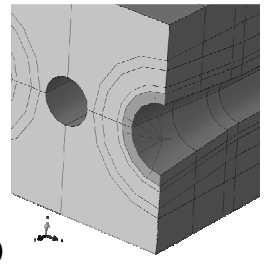

Fig. 5. Reinforcement included (light grey) in the model: a) front view; b) side view. c) Kinematic coupling between the front face of the anchor head and the centre of the tendon duct. 
Three types of finite elements are used in this model. Solid C3D8 elements ([1]), having linear approximation of displacements and full integration, digitize concrete. Therefore, they may suffer shear and volumetric locking. Nevertheless, these effects were not observed during our calculations. Shell elements S4 ([1]) are created over the areas of the anchor heads. The S4 has 4 nodes, linear shape functions, full $2 \times 2$ Gauss-Legendre in-plane integral rule, and some additional procedures preventing the locking effect. Truss T3D2 ([1]) elements are utilized to construct a numerical representation of reinforcement. The T3D2 is a straight element, having two nodes, a linear position, and displacement interpolation, and is under constant stress. These three finite elements are depicted in Fig. 6.

a)

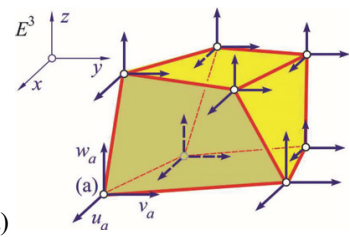

b)

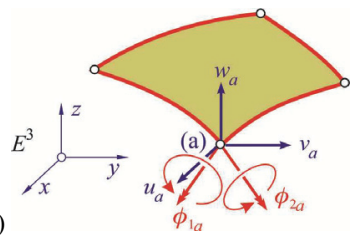

c)

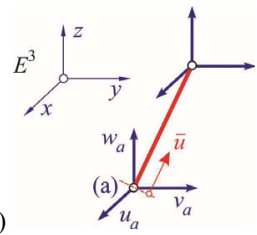

Fig. 6. The finite elements used in the numerical calculations: a) solid C3D8, b) shell S4, c) truss T3D2.

The overall mesh of finite elements in this model contains 131,741 nodes. It is most fine in the area of the anchorages and coarsens in the longitudinal duct direction (compare with Fig. 4). This approach is chosen to maintain precise results in the area where concrete damage is predicted to occur, as well as to reduce the computational time through the application of the coarse mesh in the area where only a unidirectional state of stress occurs. The mesh was checked in the field of results convergence.

The anchor heads are rigidly connected to the concrete by means of the ABAQUS skin function, which enables us to define shell elements over the faces of selected bricks. In effect, the shell elements share their nodes with the relevant nodes of the brick elements. The reinforcement included in the model is connected to concrete as well. Since it is hard to define the geometry in a way where truss elements could share their nodes with brick elements, embedded region constraint is used to create this connection. In effect, the degrees of freedom of the truss elements are constrained to the interpolated values of the corresponding degrees coming from the brick elements (see [1] for details). 


\section{MATERIAL MODEL}

Pure elastic and isotropic material characterized with an elastic modulus of $\mathrm{E}=205 \mathrm{GPa}$ and a Poisson's ratio of $v=0.3$ is assigned to all steel elements of the model.

The stress-strain relation of concrete is described by the nonlinear Concrete Damage Plasticity (CDP) law. Researchers who use CDP model have noticed that the obtained results strongly depend on the variety of some CDP parameters, and these need to therefore be carefully selected on the basis of identifications, tests and validations.

The concrete damage plasticity (CDP) model is currently one of the most popular models used for simulations of concrete behaviors in ABAQUS. This model was theoretically described in [9] and developed in [8]. Generally, the elastic-plastic response of the CDP model is described in terms of the effective stress $(\bar{\sigma})$ and the hardening variables $\left(\tilde{\boldsymbol{\varepsilon}}^{p l}\right)$, which are listed in Table 1 .

Table 1. CDP material model variables

\begin{tabular}{|c|c|c|}
\hline 1 & additive strain rate decomposition: & $\dot{\boldsymbol{\varepsilon}}=\dot{\boldsymbol{\varepsilon}}^{e l}+\dot{\boldsymbol{\varepsilon}}^{p l}$ \\
\hline 2 & effective stress: & $\overline{\boldsymbol{\sigma}} \equiv \boldsymbol{D}_{0}^{e l}\left(\boldsymbol{\varepsilon}-\boldsymbol{\varepsilon}^{p l}\right) \in\left\{\overline{\boldsymbol{\sigma}} \mid F\left(\overline{\boldsymbol{\sigma}}, \tilde{\boldsymbol{\varepsilon}}^{p l}\right) \leq 0\right\}$ \\
\hline 3 & Cauchy stress: & $\boldsymbol{\sigma}=(1-d) \overline{\boldsymbol{\sigma}}, \quad d \in[0,1]$ \\
\hline 4 & yield function: & $F\left(\overline{\boldsymbol{\sigma}}, \tilde{\boldsymbol{\varepsilon}}^{p l}\right) \leq 0$ \\
\hline 5 & nonassociated flow rule: & $\dot{\boldsymbol{\varepsilon}}^{p l}=\dot{\lambda} \frac{\partial G(\overline{\boldsymbol{\sigma}})}{\partial \overline{\boldsymbol{\sigma}}}$ \\
\hline 6 & hardening variables and rule: & $\tilde{\boldsymbol{\varepsilon}}^{p l}=\left\{\tilde{\varepsilon}_{t}^{p l}, \tilde{\varepsilon}_{c}^{p l}\right\}^{T}, \quad \dot{\tilde{\boldsymbol{\varepsilon}}}^{p l}=\boldsymbol{h}\left(\overline{\boldsymbol{\sigma}}, \tilde{\boldsymbol{\varepsilon}}^{p l}\right) \dot{\boldsymbol{\varepsilon}}^{p l}$ \\
\hline where: & $\boldsymbol{D}_{0}^{e l}-$ the initial (undamaged) elastic stiffness of the material, $\boldsymbol{D}^{e l}=(1-d) \boldsymbol{D}_{0}^{e l}-$ the degraded \\
\multicolumn{2}{|c|}{ elastic stiffness, $d=d\left(\overline{\boldsymbol{\sigma}}, \tilde{\boldsymbol{\varepsilon}}^{p l}\right)-$ the scalar stiffness degradation variable. } \\
\hline
\end{tabular}

The yield function, $F\left(\overline{\boldsymbol{\sigma}}, \tilde{\boldsymbol{\varepsilon}}^{p l}\right)$, represents a surface in effective stress space, which determines the states of failure or damage. The plastic potential function $G(\overline{\boldsymbol{\sigma}})$ is defined in the effective stress space $(\overline{\boldsymbol{\sigma}})$. The plastic multiplier $\dot{\lambda}$ and $F\left(\overline{\boldsymbol{\sigma}}, \tilde{\varepsilon}^{p l}\right)$ obeys the Kuhn-Tucker conditions: $\dot{\lambda} \geq 0, F \leq 0$, $\dot{\lambda} F=0$.

The main assumptions of this CDP model are defined below.

- Two damage mechanisms are introduced: compressive crushing $\left(d_{c}=d_{c}\left(\tilde{\varepsilon}_{c}^{p}\right)\right.$, Fig. 7a $)$ and tensile cracking $\left(d_{t}=d_{t}\left(\tilde{\varepsilon}_{t}^{p}\right)\right.$, Fig. $\left.7 \mathrm{~b}\right)$ of concrete; the $t$ and $c$ refer to tension and compression, respectively. 
- Material stiffness is reduced by two damage parameters, separately for tension $d_{t}=d_{t}\left(\tilde{\varepsilon}_{t}^{p}\right)$ and compression $d_{c}=d_{c}\left(\tilde{\varepsilon}_{c}^{p}\right)$.

- The yield function is the flow potential hyperbolic function of:

$$
F\left(\overline{\boldsymbol{\sigma}}, \tilde{\boldsymbol{\varepsilon}}^{p l}\right)=\frac{1}{1-\alpha}\left(\bar{q}-3 \alpha \bar{p}+\beta\left(\tilde{\boldsymbol{\varepsilon}}^{p l}\right)\left\langle\hat{\bar{\sigma}}_{\text {max }}\right\rangle-\gamma\left\langle\hat{\bar{\sigma}}_{\text {max }}\right\rangle\right)-\bar{\sigma}_{c}\left(\tilde{\varepsilon}_{c}^{p l}\right) \leq 0,
$$

where:

$\bar{p}=-\frac{1}{3} \overline{\boldsymbol{\sigma}} \cdot \mathbf{I}-$ effective hydrostatic stress, $\bar{q}=\sqrt{\frac{3}{2} \overline{\boldsymbol{S}} \cdot \overline{\boldsymbol{S}}}-$ Mises equivalent effective stress, $\overline{\boldsymbol{S}}=\overline{\boldsymbol{\sigma}}+\bar{p} \mathbf{I}-$ the deviatoric part of $\overline{\boldsymbol{\sigma}}, \hat{\bar{\sigma}}_{\max }-$ the maximum eigenvalue of $\overline{\boldsymbol{\sigma}},\langle\bullet\rangle-$ the Macauley bracket, which is defined as $\langle x\rangle=\frac{1}{2}(|x|+x)$.

Consequently, dimensionless material constants $\alpha, \gamma, K_{c}$ and function $\beta\left(\tilde{\boldsymbol{\varepsilon}}^{p l}\right)$ are introduced:

$$
\alpha=\frac{\left(\sigma_{b 0} / \sigma_{c 0}\right)-1}{2\left(\sigma_{b 0} / \sigma_{c 0}\right)-1}, \gamma=\frac{3\left(1-K_{c}\right)}{2 K_{c}-1}, K_{c}=\frac{\bar{q}_{T M \equiv \text { Tensile Meridian }}}{\bar{q}_{C M \equiv \text { Compressive Meridian }}}, \beta\left(\tilde{\boldsymbol{\varepsilon}}^{p l}\right)=(1-\alpha) \frac{\bar{\sigma}_{c}\left(\tilde{\varepsilon}_{c}^{p l}\right)}{\bar{\sigma}_{t}\left(\tilde{\varepsilon}_{t}^{p l}\right)}-(1+\alpha)
$$

where:

$\sigma_{b 0}-$ initial equibiaxial compressive yield stress, $\sigma_{c 0}$ - initial uniaxial compressive yield stress. $\bar{\sigma}_{t}$ and $\bar{\sigma}_{c}$ - the effective tensile and compressive cohesion stresses, respectively

- Plastic flow is nonassociated with a continuous and smooth plastic potential function:

$$
G=\sqrt{\left(\epsilon \sigma_{t 0} \tan \psi\right)^{2}+\bar{q}^{2}}-\bar{p} \tan \psi
$$

where:

$\psi-$ the dilation angle in the $p-q$ plane, $\sigma_{t 0}-$ the uniaxial tensile stress at failure (Fig. 7), $\epsilon-$ eccentricity parameter. 

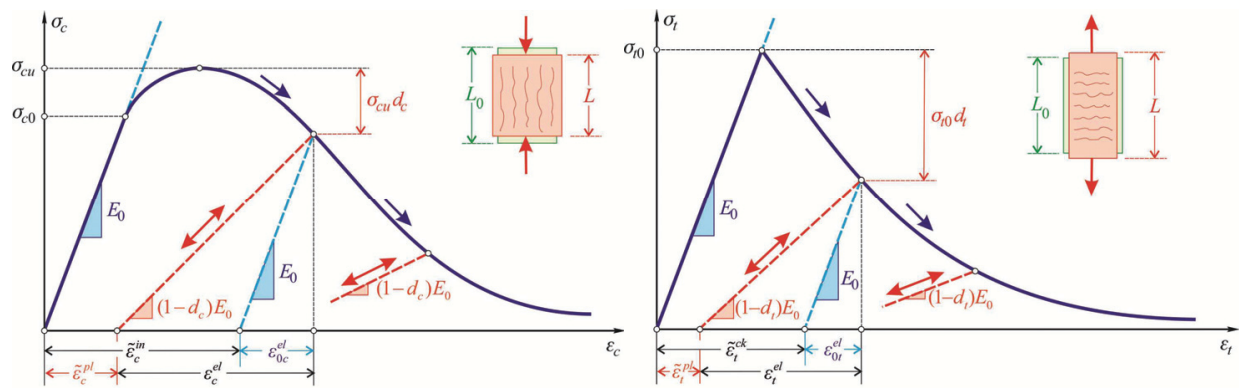

Fig. 7. Response of concrete to uniaxial loading in compression $\left(\sigma_{c}-\varepsilon_{c}\right)$ and tension $\left(\sigma_{t}-\varepsilon_{t}\right)$.

For a full definition of the CDP model in ABAQUS, the following parameters should be given:

A dilation angle $\psi$ in the $p-q$ plane,

$\Delta$ flow potential eccentricity $\epsilon$,

$\Delta$ ratio $\sigma_{b 0} / \sigma_{c 0}$ of biaxial compressive yield stress to uniaxial compressive yield stress,

$\Delta$ ratio $K_{c}$ of the second stress invariant on the tensile meridian to that on the compressive meridian for the yield function,

$\Delta$ the $\sigma_{c}-\varepsilon_{c}$ relation for compression of concrete as a set of points (Fig. 7),

$\Delta$ the $\sigma_{t}-\varepsilon_{t}$ relation for tension of concrete as a set of points (Fig. 7) or, optional, fracture energy $G_{f}$ (see e.g. [11]).

There are also some optional parameters used for the purpose of viscoplastic regularization of the constitutive equations, namely the viscosity parameter $\mu$ which represents the relaxation time of the viscoplastic system and damage conditions for compression and tension.

The CDP material parameters determined for C40/50 concrete are extensively described and validated in paper [6]. Nevertheless, the data presented in [6] is partially based on experimental work presented in [5]. The same concrete was used in the analyzed bridge, which was confirmed by measurements carried out on specimens taken from the construction site right before concrete pouring. The parameters required for input into Abaqus are given in Table 2 and Table 3.

Table 2. Material parameters of the CDP model for concrete class C40/50 (taken from [6])

\begin{tabular}{|c|c|c|c|}
\hline \multirow{2}{*}{$\begin{array}{c}\text { Material } \\
\text { parameters }\end{array}$} & \multirow{2}{*}{$\mathbf{C 4 0 / 5 0}$} & \multicolumn{2}{|c|}{ Parameters of CDP model } \\
\cline { 3 - 4 } & & $\psi$ & $38^{\circ}$ \\
\hline \multicolumn{2}{|c|}{ Concrete elasticity } & $\epsilon$ & 1 \\
\hline$E[G P a]$ & 19.7 & $\sigma_{b 0} / \sigma_{c}$ & 1.12 \\
\hline$v$ & 0.19 & $K_{\mathrm{c}}$ & 0.846 \\
\hline
\end{tabular}


Table 3. Material parameters of the CDP model for concrete class C40/50, required to define $\sigma_{c}-\varepsilon_{c}^{i n}$ and $\sigma_{t}$ $\varepsilon_{t}^{\text {in }}$ relations (taken from [6]).

\begin{tabular}{|c|c|c|c|}
\hline \multicolumn{2}{|c|}{ Concrete compression } & \multicolumn{2}{c|}{ Concrete tension } \\
\hline$\varepsilon_{c}^{\text {in }[-]}$ & $\sigma_{c}[M P a]$ & $\varepsilon_{t}^{\text {in }}[-]$ & $\sigma_{t}[M P a]$ \\
\hline 0.0 & 15.0 & 0.0 & 1.998930 \\
\hline 0.0000747307 & 20.197804 & 0.000033330 & 2.842000 \\
\hline 0.0000988479 & 30.000609 & 0.000160427 & 1.869810 \\
\hline 0.000154123 & 40.303781 & 0.000279763 & 0.862723 \\
\hline 0.000761538 & 50.007692 & 0.000684593 & 0.226254 \\
\hline 0.002557559 & 40.236090 & 0.001086730 & 0.056576 \\
\hline 0.005675431 & 20.184000 & \multicolumn{2}{|c}{} \\
\cline { 1 - 2 } 0.011733119 & 5.257557 & \multicolumn{2}{|c}{} \\
\cline { 1 - 2 } & \multicolumn{2}{|c}{}
\end{tabular}

Damage parameters $d_{c}$ and $d_{t}$ also required for the material law input data can be easily calculated based on the information given in Fig. 7 and data from Table 3.

In the calculations regarding concrete behaviour presented in this work, we utilized concrete properties presented in Table 2 and Table 3. However, we changed the value of Young's modulus to $32 \mathrm{GPa}$, since this value was identified for the specimens sampled before pouring. We assume that in such a case the remaining CDP parameters are not changed and the concrete behaviour will be recreated properly, which was confirmed later in our calculations.

\section{CALCUlations - TYPES OF ANALYSES}

Static analysis using material and geometric nonlinearities was first performed for the second considered model. Nevertheless, in this case we encountered problems with the convergence of the iterative process, which resulted in the termination of calculations at the level corresponding with the application of only $30 \%$ of the total stressing force. Therefore, new dynamic explicit calculations were established, including material and geometric nonlinearities as well. It was assumed during the dynamic calculations that the stressing loads are proportional with regard to the time of analysis. Thus, the dynamic analysis simulates the conditions of the static problem, and this approach enabled us to apply the full stressing conditions to the model.

The duration of the dynamic computations of the second model - despite the fact that it is limited only to a small part of the whole structure - was 96 hours and 26 minutes. The calculations were carried out on a work station with four $3.4 \mathrm{GHz}$ processors and 16GB of RAM memory. 


\section{COMPARISON OF FEM RESULTS AND IN SITU CRACK PATTERNS}

Correlation between the prestressing force in tendon and anchor head displacements was monitored during the analysis (Fig. 8). It reveals two noticeable growths of anchor head displacements for: $\sim 5400 \mathrm{kN}$ and $\sim 6100 \mathrm{kN}$, which indicate that an undesirable failure process was initiated within the concrete.

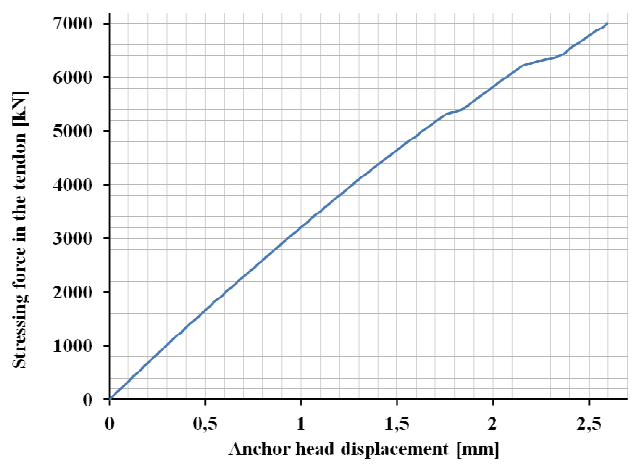

Fig. 8. Relation between the prestressing force in tendon and anchor head displacements, monitored during analysis.

The distribution of scalar concrete damage parameters in tension (DAMAGET) on the front face of the model shown in Fig. 9a is observed in the last increment of the dynamic analysis $(100 \%$ of stressing force is applied to the model). The DAMAGET parameter implies the following interpretation: DAMAGET $=0$ means that there is no damage due to tension in the concrete, whereas DAMAGET $=1$ indicates that the concrete failed fully under tension. According to [6], DAMAGET allows us to identify developments of crack patterns in concrete. Fig. 9a exposes mainly cracks, marked with green ellipses, developing laterally over the top of the anchor heads, and a vertical crack marked with yellow ellipses. However, during the onsite observation of the bridge, vertical cracks were not spotted (compare with Fig. 2). Therefore, in order to properly verify the visibility of the cracks from the numerical simulation, the DAMAGET distributions in section A-A (see Fig. 9a) are also checked and presented in Fig. 9b. The analysed lateral and vertical cracks are marked with the same colours.

The patterns of DAMAGET variable from Fig. 9b show that the vertical crack on the front surface is shallow, therefore it might have been difficult to see, as opposed to the main lateral crack 
(in fact a fracture), which penetrates deeply into the concrete. Thus, the crack distributions shown in Fig. 9a correspond with the observed ones (compare with Fig. 2).

a)

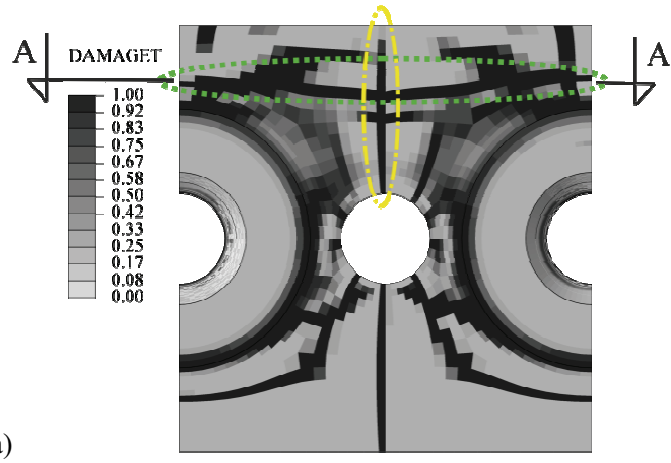

b)

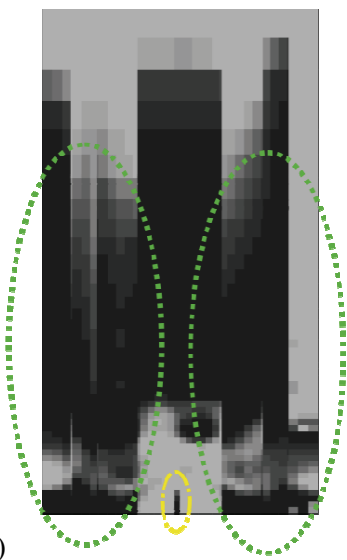

Fig. 9. a) Distribution of DAMAGET parameters (quilt contour) on the front face of the model in the last increment of dynamic analysis. b) Distribution of DAMAGET parameters (quilt contour) in section A-A .

Additionally, it is worth mentioning that in this type of analysis it was important to monitor the DAMAGET parameters at the elemental integration points. When the contours of DAMAGET were created from averaged nodal values of adjacent elements, the crack patterns became blurred and therefore unnoticeable, which could lead to false conclusions.

We would also like to emphasize that no problems were reported regarding a too high temperature of concrete during its curing, which we believe is due to the following reasons; the structure was poured between spring and summer, the upper bridge slab is relatively thin in the vicinity of the anchorages, and many ducts were designed inside the slab, therefore the concrete was easily ventilated and could cool down during curing in the section of the bridge analysed. In effect, there is a very low possibility that, vital to the purpose of concrete load capacity, shrinkage cracks were created as a consequence of high temperature gradients from the hydration processes during the curing period (see also [3]). Therefore, the cracks found at the site appeared mainly because of stressing.

In addition, it would be favorable to perform laser scanning in order to identify precisely the geometry of the cracked concrete parts of the bridge, for instance, as it is described in [2]. Nevertheless, further experiments were not possible due to the site's schedule. Moreover, an 
application of structural health monitoring, as in e.g. [7] or [10], could give an answer to whether or not the numerical estimations are correct.

\section{FINAL REMARKS}

Local analysis, as a part of broader research, of failure mechanisms occurring during centric tensioning in cable anchorages of multi-span box sections of a bridge is shown in this paper. Investigation regarding crack pattern development enables us to formulate following conclusions. The local character of the failure phenomenon which was demonstrated in the so-called global analysis of the bridge allowed us to create a small model of the selected section of the bridge. The precise local model ought to include all elements of the structure important in terms of the analyzed phenomenon, and recreate the state of the structure during the investigative process; tensioning, in this case. Nonlinear material law with the degradation of elastic constants used to describe the concrete enabled us to estimate crack pattern development in the section of the bridge examined. It is important to check depth of the crack and also its spatial propagation directions in order to justify the visibility of cracks, which was achieved via DAMAGET parameters in this project. Finally, the local analysis described in this paper, limited strictly to mechanical effects, indicates that damage of the bridge tensioning cable anchorages could have occurred as a consequence of the applied variant of reinforcement grids and an insufficient volume of concrete between tensioning ducts.

\section{ACKNOWLEDGEMENTS}

This work is an extension of the conference paper [4] presented during the XIV Conference on Computational Methods in Engineering TKI'2016 (XIV Konferencja Naukowo-Techniczna Techniki Komputerowe w Inżynierii TKI'2016), held between the 18th and the 21st of October in Teresin, near Warsaw.

Abaqus calculations were performed at the Academic Computer Centre in Gdańsk. B. Sobczyk is supported by the Gdansk University of Technology (Poland), Faculty of Civil and Environmental Engineering, Young Scientist Support Program (2016/2017 edition). 


\section{REFERENCES}

1. Abaqus 6.14 manual.

2. M. Bernat, A. Janowski, S. Rzepa, A. Sobieraj, J. Szulwic, "Studies on the use of terrestrial laser scanning in the maintenance of buildings belonging to the cultural heritage", Proceedings of the 14th Geoconference on Informatics, Geoinformatics and Remote Sensing, SGEM.ORG, Albena, Bulgaria, Vol. 3, pp 307-318, 2014.

3. J. Chróścielewski J., A. Mariak, A. Sabik, B. Meronk, K. Wilde, "Monitoring of concrete curing in extradosed bridge supported by numerical simulation", Adv. Sci. Technol. Res. J 10(32): 254-262, 2016.

4. J. Chróścielewski, M. Miśkiewicz, Ł. Pyrzowski, B. Sobczyk, "Analiza numeryczna uszkodzeń stref zakotwień kabli sprężających konstrukcji mostowej", Proceedings of the XIV Conference on Computational Methods in Engineering TKI'2016. Teresin, Poland, pp 1-2, 2016.

5. S. J. Green, S. R. Swanson, "Static constitutive relations for concrete", AWFL-TR-72-244, U.S.Air Force Weapon Laboratory, Kirtland Air Force Base, NM, 1973.

6. T. Jankowiak T., T. Łodygowski, "Identification of parameters of concrete damage plasticity constitutive model", Foundations of Civil and Environmental Engineering 6: 53-69, 2005.

7. W. Kaminski, K. Makowska, M. Miśkiewicz, J. Szulwic, K. Wilde, "System of monitoring of the Forest Opera in Sopot structure and roofing" 15th International Multidisciplinary Scientific GeoConference SGEM 2015 Proceedings vol. 2, pp 471-482, 2015.

8. J. Lee, G. Fenves, "Plastic-damage model for cyclic loading of concrete structures", J. Eng. Mech., 124(8): 892-900, 1998.

9. J. Lubliner, J. Oliver, S. Oller, E. Oate, "A plastic-damage model for concrete", Int. J. Solids Struct., 25(3): 299-326, 1989.

10. M. Rucka, K. Wilde, "Experimental study on ultrasonic monitoring of splitting failure in reinforced concrete", Journal of Nondestructive Evaluation 32(4): 372-383, 2013.

11. M. Szczecina, A. Winnicki, "Calibration of the CDP model parameters in ABAQUS" Proceedings of the 2015 World Congress on Advances in Structural Engineering and Mechanics (ASEM15), Incheon, Korea, pp 25-29, 2015. 


\section{LIST OF FIGURES AND TABLES.}

Fig. 1. Cross-section of the analyzed bridge with the ducts of centric prestressing marked with green ellipses.

Rys. 1. Przekrój analizowanego mostu z kanałami centrycznego sprężenia zaznaczonymi zielonymi elipsami.

Fig. 2. Damages and sketches of anchor zone reinforcement grids.

Rys. 2. Uszkodzenia betonu oraz szkic siatki zbrojeniowej strefy docisku stref zakotwień kabli sprężających.

Fig. 3. Visualisation of the quasi-axisymmetric model: a) concrete and anchor head highlighted in light grey; b) reinforcement of the anchor zone coloured in light grey.

Rys. 3. Wizualizacje modelu numerycznego quasi osiowo symetrycznego: a) beton i głowica kabli sprężających (oznaczone jasno szarym koloerm); b) zbrojenie strefy zakotwienia, które oznaczono jasno szarym kolorem.

Fig. 4. a) External geometry of the model. b) Steel anchor heads (light grey) in the numerical model.

Rys. 4. a) Zwnętrzna geometria modelu obliczeniowego. b) Stalowa głowica kotwiąca kable zbrojeniowe (jasno szary kolor) w modelu numerycznym.

Fig. 5. Reinforcement included (light grey) in the model: a) front view; b) side view. c) Kinematic coupling between the front face of the anchor head and the centre of the tendon duct.

Rys. 5. Zbrojenie uwzględniane w modelu numerycznym: a) widok z przodu; b) widok z boku c) Schemat sprzężenia kinematycznego pomiędzy powierzchnią czołową płyty kotwiącej i środkiem duktu sprężenia centrycznego.

Fig. 6. The finite elements used in the numerical calculations: a) solid C3D8, b) shell S4, c) truss T3D2.

Rys. 6. Elementy skończone wykorzystywane w obliczeniach numerycznych: a) bryłowe C3D8, b) powłokowe S4, c) kratownicowe T3D2.

Fig. 7. Response of concrete to uniaxial loading in compression $\left(\sigma_{c}-\varepsilon_{c}\right)$ and tension $\left(\sigma_{t}-\varepsilon_{t}\right)$.

Rys. 7. Odpoweidź betonu pod obciążeniem w stanie jednoosiowego ściskania $\left(\sigma_{c}-\varepsilon_{c}\right)$ i rozciągania $\left(\sigma_{t}-\varepsilon_{t}\right)$.

Fig. 8. Relation between the prestressing force in tendon and anchor head displacements, monitored during analysis.

Rys. 8. Rozkład parametru DAMAGET na czołowej powierzhcni modelu numerycznego w ostatnim kroku analizy.

Fig. 9. a) Distribution of DAMAGET parameters (quilt contour) on the front face of the model in the last increment of dynamic analysis. b) Distribution of DAMAGET parameters (quilt contour) in section A-A .

Rys. 9. a) Rozkład parametru DAMAGET (kontur typu quilt) na powierzchni czołowej modelu w ostatnim kroku analizy dynamicznej. b) Rozkład parametru DAMAGET (kontur typu quilt) w przekroju A-A.

Table 1. CDP material model variables

Tabela 1. Równania opisujące model materiałowy CDP

Table 2. Material parameters of the CDP model for concrete class C40/50 (taken from [6])

Tabela 2. Parametry materiałowe modelu CDP dla betonu C40/50 (zgodnie z [6])

Table 3. Material parameters of the CDP model for concrete class $\mathrm{C} 40 / 50$, required to define $\sigma_{c}-\varepsilon_{c}^{i n}$ and $\sigma_{t} \varepsilon_{t}^{i n}$ relations (taken from 6).

Tabela 3. Parametry materiałowe modelu CDP dla betonu C40/50, wymagane do zdefiniowana zależności $\sigma_{c}-\varepsilon_{c}^{\text {in }}$ oraz $\sigma_{t} \varepsilon_{t}^{\text {in }}$ (zgodnie z [6]) 


\section{ANALIZA NUMERYCZNA USZKODZEŃ STREF ZAKOTWIEŃ KABLI SPRĘŻAJĄCYCH KONSTRUKCJI MOSTOWEJ}

Keywords: awaria konstrukcji, zniszczenie betonu, zarysowanie konstrukcji, analiza MES, ABAQUS

\section{STRESZCZENIE:}

W trakcie prac budowlanych związanych z wykonaniem centrycznego sprężenia podłużnego przęseł mostu doszło do silnych zarysowań betonu bloków kotwiących. Pojawiły się znaczne rysy/pęknięcia poziome w strefie zakotwień na wysokości zbrojenia siatkami. W referacie podjęto próbę opisu mechanizmu zniszczenia strefy zakotwień kabli wewnętrznych sprężenia podłużnego jednego z przęseł mostu z wykorzystaniem środowiska metody elementów skończonych (MES) systemu ABAQUS. Wykonano symulację numeryczną niepożądanych zjawisk lokalnych zarysowania w blokach kotwiących kable, które wystąpiło w trakcie procesu sprężania konstrukcji. Miała to na celu ustalenie, od strony mechaniki, przyczyn ich powstania, w kontekście zaprojektowanego i wykonstruowanego układu zbrojenia.

Ze względu na lokalny charakter zjawiska zarysowania, model numeryczny ograniczono do opisu wycinka płyty górnej skrzynki pomostu z jednym nieużywanym tunelem kablowym i dwoma sąsiadującymi kanałami aktywnymi, poprzez które przekazywana jest siła sprężająca na konstrukcję. Biorąc pod uwagę szeregowy układ kotwień grupy kabli sprężanych taką samą siłą, założono na bokach bryły, formowanych płaszczyzną przechodzącą przez środki głowic, obciążenie i warunki brzegowe typu symetrii cyklicznej, zaś na ścianie tylnej warunki odpowiadające symetrii poprzecznej z dodatkową blokadą ruchu pionowego układu. Poza opisem bryły betonu, uwzględniono strukturę zbrojenia głównego mostu i zbrojenie lokalne strefy zakotwienia oraz stalowe płyty oporowe. W dyskretyzacji układu zastosowano następujące elementy skończone: bryłowy C3D8 dla części betonowych; powłokowy S4 dla płyt oporowych; kratownicowy T3D2 dla zbrojenia. Wszystkie elementy są klasy C0 o liniowej aproksymacji przemieszczeń. Siatka podziału zawiera łącznie 131741 węzłów. Płyty oporowe utworzono przy pomocy funkcji skin, która pozwala na zdefiniowanie elementów powłokowych na wydzielonych powierzchniach obszaru. Elementy te są połączone z bryłą w sposób sztywny. Zbrojenie uwzględnia interakcję z betonem typu embedded region, co sprowadza się do sprzężenia odpowiednich stopni swobody węzłów związanych ze zbrojeniem ze stopniami swobody węzłów części betonowej.

Obciążenie odpowiadające realizacji osiowych sił sprężających z uwzględnieniem specyfiki kontaktu prasy naciągowej realizowano przez odpowiednie sprzężenie kinematyczne powierzchni czołowej płyty oporowej głowicy do punktów centralnych kanałów kablowych. Na te punkty dodatkowo nałożono warunki brzegowe uniemożliwiające ich ruch pionowy.

W modelu zastosowano następujące modele materiałowe. Częściom stalowym przypisano materiał sprężysty izotropowy, o standardowych parametrach: $\mathrm{E}=205 \mathrm{GPa}, \mathrm{v}=0.3$. Beton opisuje nieliniowy model materiału Concrete Damage Plasticity o parametrach przyjętych na podstawie dostępnej literatury. Parametry te odpowiadają materiałowi wbudowanemu w moście. Jest to związek konstytutywny zakładający początkowe wzmocnienie, a następnie osłabienie materiału zarówno przy ściskaniu jak i rozciąganiu. Ponadto, po zapoczątkowaniu procesu osłabienia następuje degradacja ujęta w zmianach parametrów materiałowych.

W pracy realizowano następujące obliczenia. W pierwszej kolejności podjęto próbę ich realizacji przy pomocy statyki nieliniowej. Jednak ze względu na trudności ze zbieżnością procesu iteracyjnego ujawniające się na poziomie $\sim 30 \%$ obciążenia docelowego, zdecydowano się przejść na analizę typu dynamic, explicit, która pozwoliła na przyłożenie 
$100 \%$ obciążenia projektowego. W ramach analizy dynamicznej wzrost obciążenia traktowano jako proporcjonalny w funkcji czasu.

Symulacja numeryczna procesu sprężania wskazuje głównie rysy propagujące poziomo nad górną częścią płyt oporowych, których rozkłady oszacowano przy pomocy parametru DAMAGET. Podczas oględzin mostu na budowie nie zauważono jednak wyraźnie rysy pionowej wykazanej w symulacji. W celu weryfikacji widoczności tych rys w bryle betonu sprawdzono głębokość rys w przekroju poziomym. Wykazał on, że rysa pionowa jest płytka, powierzchniowa i stąd mogła być mało widoczna, w przeciwieństwie do wyraźnej, dominującej rysy, a w zasadzie pęknięcia poziomego penetrującego głęboko w beton.

Przeprowadzone badania dają podstawę do sformułowania następujących wniosków. Miejscowy charakter zjawiska, wykazany w tzw. analizie globalnej całego układu określającej zakres i obszar jego oddziaływania, uprawnia do prowadzenia analiz na tzw. poziomie lokalnym. Lokalny model szczegółowy fragmentu ustroju powinien zawierać wszystkie elementy istotne z punktu widzenia badanego zjawiska i ujmować stan całego układu, tutaj podczas sprężania mostu. Nieliniowe prawo materiałowe z degradacją przyjęte do opisu materiału pozwala na oszacowanie rozkładów powstawania rys w betonie. Ocena intensywności zarysowań wymaga uwzględnienia ich rozkładów przestrzennych, w tym zasięg ich wgłębnej propagacji. Przeprowadzone analizy lokalne, nawet ograniczone tu tylko do oddziaływań mechanicznych, wskazały, że tego typu uszkodzenia mogą powstać w przypadku stosowanego rozważanego wariantu zbrojenia strefy zakotwienia i zbyt małej objętości betonu w bloku kotwiącym. 